\title{
The northern river shark Glyphis sp. C (Carcharhinidae) discovered in Western Australia
}

\author{
DEAN C. THORBURN \& DAVID L. MORGAN \\ Centre for Fish and Fisheries Research, Murdoch University, South St Murdoch, Western Australia 6150; \\ thorburn@murdoch.edu.au,d.morgan@murdoch.edu.au
}

\begin{abstract}
Seven specimens of Glyphis sp. C were collected from macrotidal mangrove systems near the town of Derby in the Kimberley region of Western Australia, which represents the first capture in this state. The five males and two females ranged in length from 906 to $1418 \mathrm{~mm}$ TL, weighed between 5150 and $18640 \mathrm{~g}$ and had a vertebral count range outside that previously reported for the species, i.e. 140-151 cf 147-148. The unusually high incidence of fused vertebrae and spinal deformation may suggest a small gene pool in this population. Previous occurrences of this species were restricted to rivers in the Northern Territory (Australia) and Papua New Guinea. The presence of a small eye (mean diameter $0.87 \%$ of total length), large dorsal and pectoral fins, and well defined sensory ampullae may be reflective of living in an environment subjected to extreme turbidity and flows.
\end{abstract}

Key words: Glyphis, Carcharhinidae, Kimberley, northern river shark

\section{Introduction}

The northern river shark Glyphis sp. C (see Fig. 2) is a cryptic carcharhinid that was previously known from only three specimens from the Fly River in Papua New Guinea and five specimens from the Adelaide and East Alligator rivers in the Northern Territory of Australia (Taniuchi et al. 1991; Compagno \& Niem 1998; Larson 2000). Only two species of Glyphis have been recorded in Australian river systems, these being Glyphis sp. A and C, however, the number of congeners that exist worldwide is uncertain, with a lack of specimens hindering the formal description of three of the four or five species within the genus, i.e. Glyphis sp. A, Glyphis sp. B and Glyphis sp. C. The genus is distinguished by a second dorsal fin height between one half and three fifths that of the first (Last \& Stevens 1994), and the possession of non-crescentic, longitudinal precaudal pits (Compagno \& Niem 1998). Glyphis sp. C is differentiated from Glyphis sp. A and B by a lower vertebral 

(Compagno \& Niem 1998).

In June 2002, a single specimen of Glyphis sp. C was collected by one of the authors whilst sampling for barramundi Lates calcarifer (Bloch, 1790) in a macrotidal mangrove system north of Derby (Doctors Creek) (Morgan et al. 2004). This capture was previously reported by Pogonoski and Pollard (2003) as being from the Fitzroy River. As a consequence of this enigmatic occurrence, funding was sought from Environment Australia to establish whether this endangered (as listed in the Environment Protection and Biodiversity Conservation Act 1999), or critically endangered (as listed in Pogonoski \& Pollard 2003 ) species, is well represented in the area.

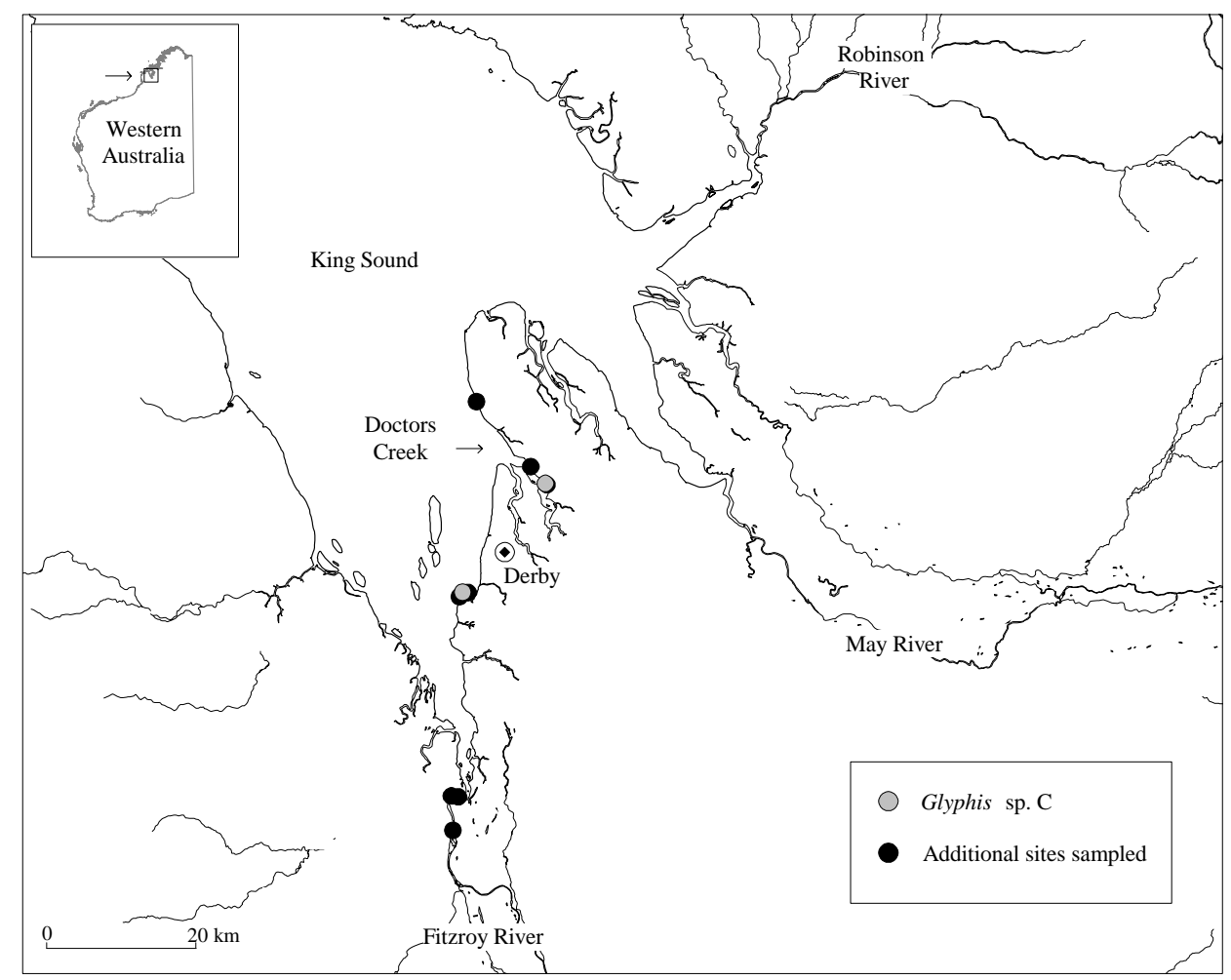

FIGURE 1. The sites sampled and capture locations for Glyphis sp. C in King Sound, and in the Fitzroy River during June 2003.

\section{Materials and Methods}

In June 2003, seven sites were sampled in macrotidal mangrove areas in King Sound including, and adjacent to, Doctors Creek (Fig. 1), using a selection of monofilament gill nets and baited lines. Three sites in the lower Fitzroy River (the nearest major river system) were also sampled. On each sampling occasion the salinity and temperature were 
recorded. Habitat parameters such as tidal movement, water clarity (secchi) and depth were also collected.

The total length (TL) (mm), weight $(\mathrm{g})$, and height of the first and second dorsal fins $(\mathrm{mm})$ were recorded for each specimen. In addition, six specimens were X-rayed and one was dissected to determine their vertebral count. In males, maturation was determined by the development and level of calcification of the claspers, while the maturity of the largest female specimen was determined via dissection, using the criteria described by Conrath (2004), relating to the condition of ova in the ovary, and the developmental stage of the oviduct.

\section{Results}

Distribution and habitat. In addition to the first specimen caught in 2002 (WAM P.32597.001) (Morgan et al. 2002; Morgan et al. 2004), six Glyphis sp. C were captured from two of the seven macrotidal marine sites sampled (WAM P.32598.001, WAM P.32599.001, WAM P.32600.001 four individuals) (Table 1, Figs. 1 \& 2). None was captured in the Fitzroy River. The original specimen, a semi-mature male measuring $994 \mathrm{~mm}$ TL (Table 1, Fig. 3), was captured at the entrance of a small tributary in the northern branch of Doctors Creek. A further two specimens (WAM P.32598.001, WAM P.32599.001) were captured at this site during this study, with the remaining four being captured at the mouth of another small tributary approximately $20 \mathrm{~km}$ south of the mouth of Doctors Creek (Fig. 1). Both sites were macrotidal (with tidal movements of up to $10 \mathrm{~m}$ twice daily), dominated by mangroves and had salinities between 32.0 and 36.6 parts per thousand (ppt). Water temperatures at the collection sites were between 22 and $23^{\circ} \mathrm{C}$. Sites were typified by low water clarity with secchi depths of only 3 to $4 \mathrm{~cm}$. All specimens were captured during the outgoing tide.

Morphology. Of the seven Glyphis sp. C collected, five were male, ranging in length from 906 to $1418 \mathrm{~mm}$ TL, and weighed between 5150 and $18640 \mathrm{~g}$, while the two female specimens were 957 and $1350 \mathrm{~mm}$ TL, and weighed 5970 and $16830 \mathrm{~g}$, respectively (Table 1). The mean ratio of the height of the second dorsal fin to the first dorsal fin of the six specimens collected during 2003 was 0.62 ( \pm 0.01 S.E.), and ranged from 0.58 to 0.66 ; their mean eye diameter was $0.87 \%$ ( \pm 0.04 S.E.) of total length, and ranged from 0.77 to $1.03 \%$. Only the largest male (1418 mm TL) was mature (claspers fully calcified), while the largest females were immature. The $994 \mathrm{~mm}$ TL specimen collected in 2002 had semicalcified claspers, indicating that maturation had not yet been obtained.

Vertebral counts ranged between 140 and 151, with a mean of 146 ( \pm 1.53 S.E.) (Table 1). Fusion of vertebrae and spinal deformation was present in the first specimen caught (Fig. 3) and also in the largest male and largest female collected during June 2003. A count (total) of the number of diplospondylous caudal centra for all the specimens ranged from 64 to 70 . 


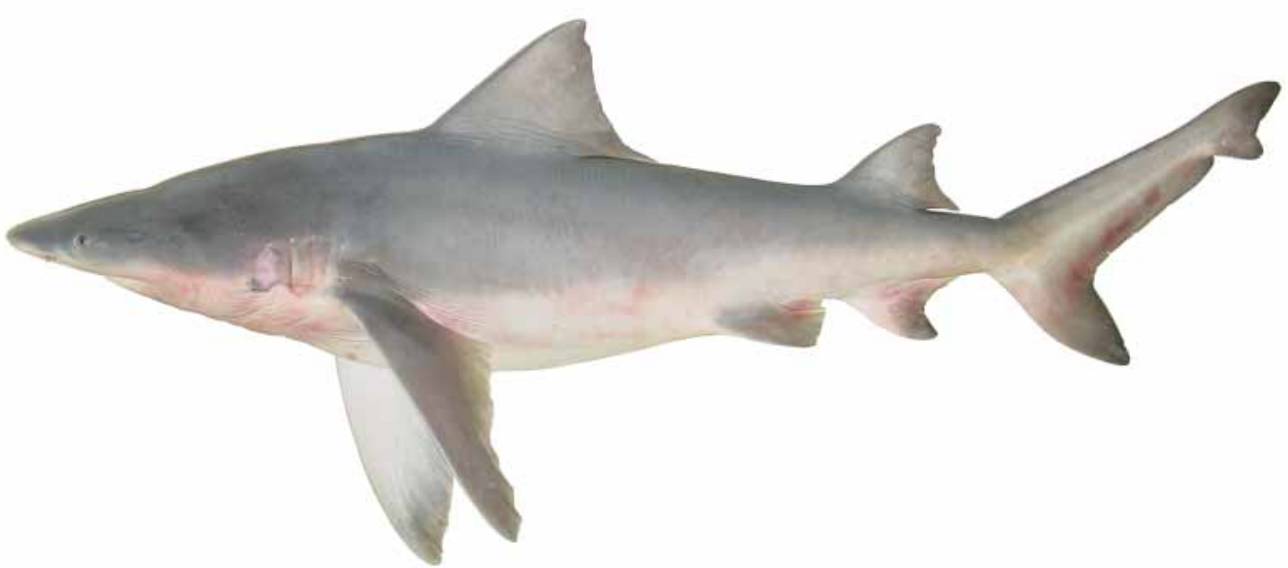

FIGURE 2. The northern river shark Glyphis sp. C (957 mm TL) from Doctors Creek (WAM P.32599.001).

\section{$\mathbf{a}$}
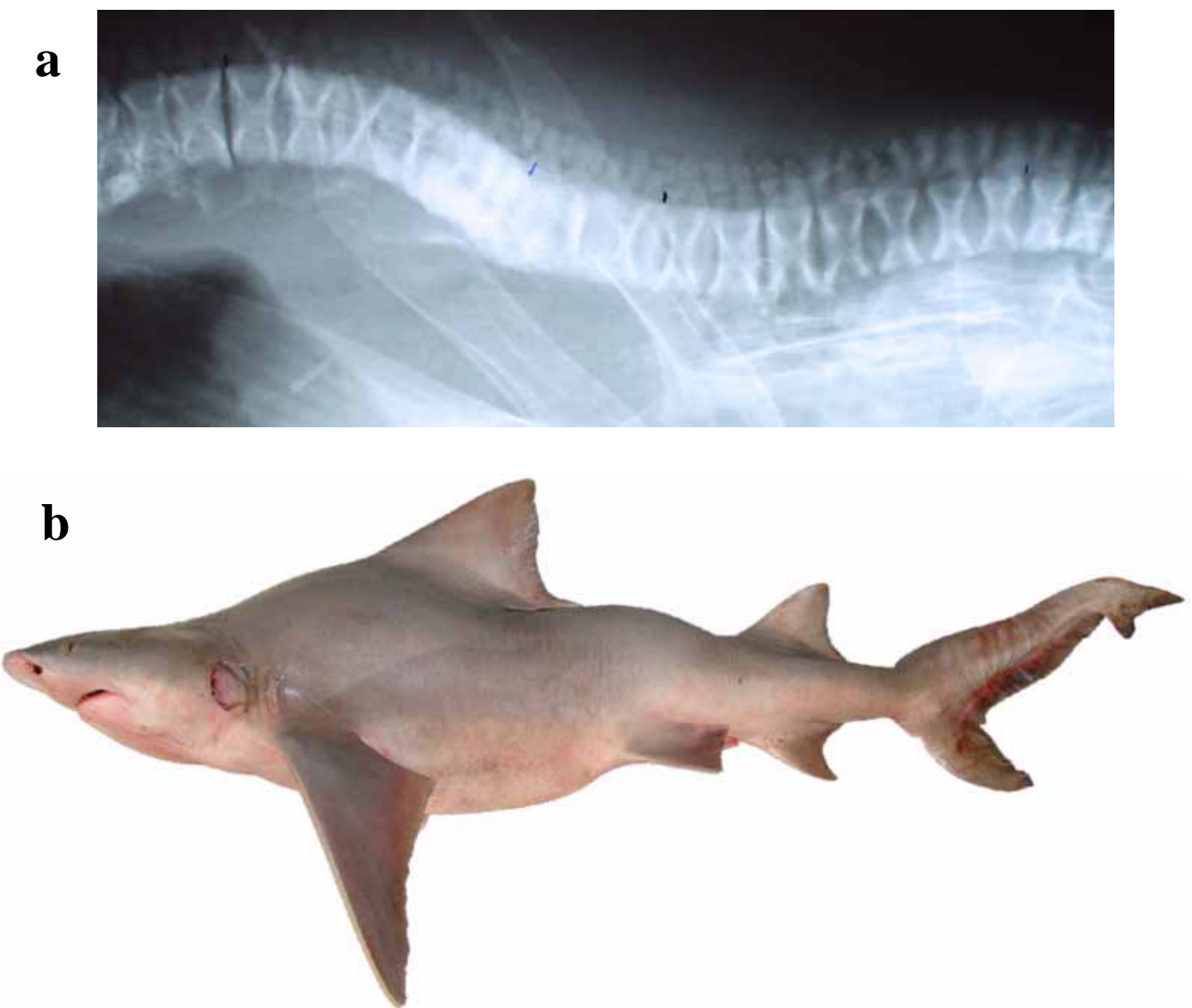

FIGURE 3. a) X-ray showing severe fusing of vertebrae and spinal curvature, and b) distorted appearance of the first Glyphis sp. C specimen (994 mm TL) collected in Western Australia (WAM P.32597.001). 

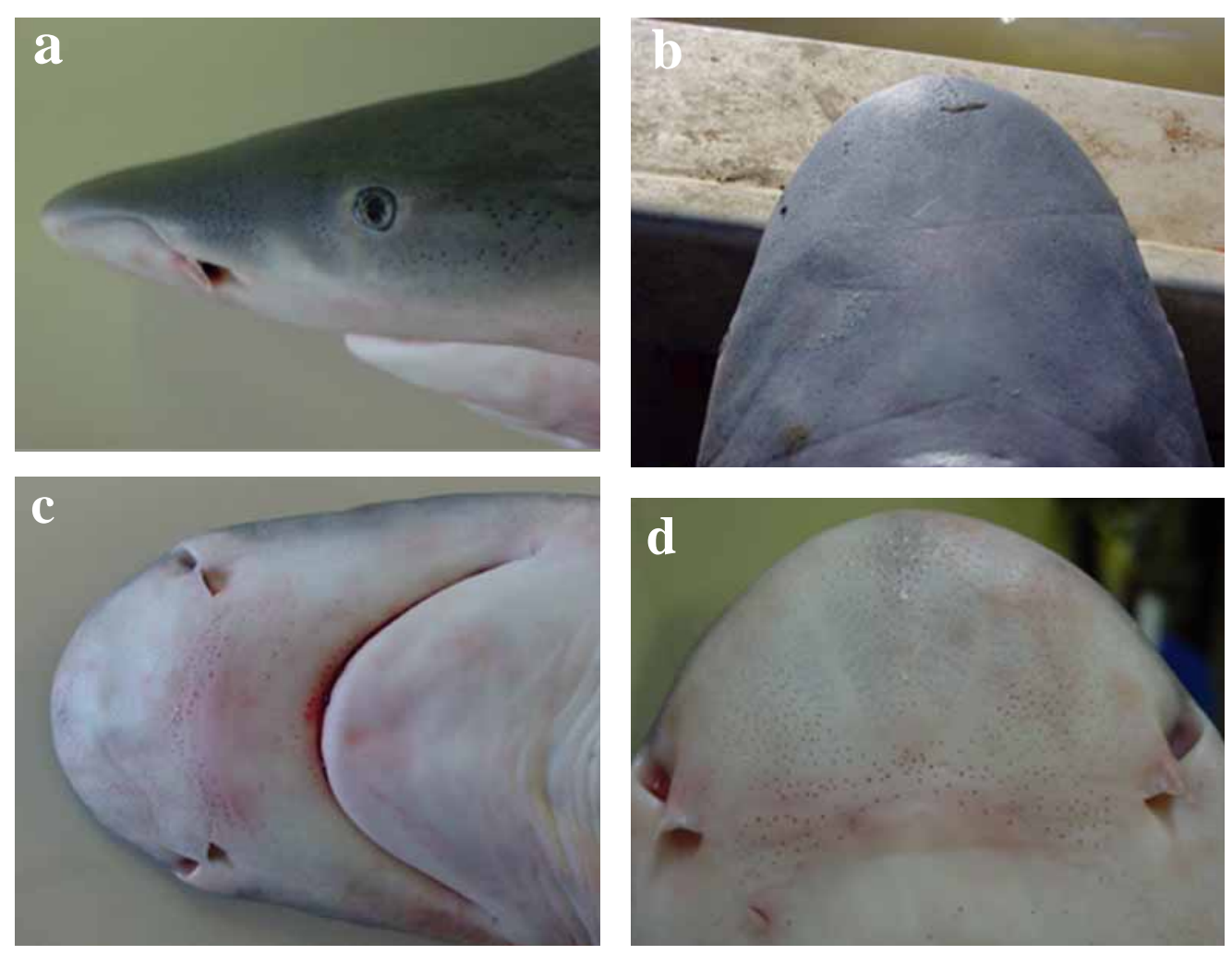

FIGURE 4. Sensory ampullae covering the head of Glyphis sp. C. Anterior (a) lateral, (b) dorsal, and (c and d) ventral sensory ampullae of Glyphis sp. C (957 mm TL) (WAM P.32599.001).

Diet. X-rays revealed that the stomachs of three of the five specimens contained forktailed catfishes (likely Arius graeffei Kner and Steindachner, 1867), identifiable by their barbed spines and distinctive head shield of the upper skull. The stomach of the dissected female contained a large piece of threadfin salmon Polydactylus macrochir (Günther, 1867).

\section{Discussion}

The results of this study suggest that the tidal creeks of King Sound, including Doctors Creek, may be an important habitat for the (critically) endangered Glyphis sp. C, with these specimens representing almost half of all those known. Although this rarity may reflect a paucity of ichthyological exploration of the remote Kimberley region of Western Australia, it should be noted that the species was not encountered during an elasmobranch survey of 160 sites throughout 39 river/creek systems of northern Australia, including 12 river/creek systems in the Kimberley (Thorburn et al. 2003). This species, as its common 
name implies, was previously only known from riverine habitats with salinities ranging from 2 to $26 \mathrm{ppt}$ (Larson 2000). During this study, however, it was only encountered in macrotidal marine conditions ( 32 to $36.6 \mathrm{ppt}$ ). Additionally, this species was not captured during an extensive study of the fish fauna at 70 sites in the freshwaters of the Fitzroy River (Morgan et al. 2002, 2004), which drains into King Sound, has a catchment of almost $90000 \mathrm{~km}^{2}$ and has the highest recorded runoff of any river in Western Australia (Anon. 1993, Storey 1998). Furthermore, studies of Kimberley rivers by Allen (1975), Hutchins $(1977,1981)$ and Allen and Leggett (1990) did not record Glyphis sp. C.

TABLE 1. Western Australian Museum (WAM) specimen number, capture location, sex, maturity, total length (TL), weight, total vertebrae, heights of the first and second dorsal fins, and dorsal fin ratio of Glyphis sp. C from King Sound. Maturity status is given as: I-immature; SM-semi-mature and; M-mature.

\begin{tabular}{cccccccccc}
\hline $\begin{array}{c}\text { WAM } \\
\text { number }\end{array}$ & Location & $\begin{array}{c}\text { Sex } \\
\text { Matu- } \\
\text { rity }\end{array}$ & & $\begin{array}{c}\text { TL } \\
(\mathrm{mm})\end{array}$ & $\begin{array}{c}\text { Weight } \\
(\mathrm{g})\end{array}$ & $\begin{array}{c}\text { Total } \\
\text { vertebrae }\end{array}$ & $\begin{array}{c}\text { First dorsal } \\
\text { height }(\mathrm{mm})\end{array}$ & $\begin{array}{c}\text { Second } \\
\text { dorsal } \\
\text { height } \\
(\mathrm{mm})\end{array}$ & $\begin{array}{c}\text { Dorsal fin } \\
\text { ratio }\end{array}$ \\
\hline P.32597.001 Doctors Ck & M & SM & 994 & - & 140 & - & - & - \\
P.32598.001 & Doctors Ck & M & I & 906 & 5150 & 147 & 88.14 & 58.60 & 0.66 \\
P.32599.001 & Doctors Ck & F & I & 957 & 5970 & 147 & 100.98 & 63.79 & 0.63 \\
P.32600.001 & King Sound & F & I & 1350 & 16830 & 151 & 142.26 & 82.91 & 0.58 \\
P.32600.001 King Sound & M & I & 1191 & 10560 & 148 & 129.16 & 82.66 & 0.64 \\
P.32600.001 King Sound & M & M & 1418 & 18640 & 142 & 150.70 & 86.84 & 0.58 \\
P.32600.001 King Sound & M & I & 1022 & 7700 & 147 & 98.53 & 59.72 & 0.61 \\
\hline
\end{tabular}

Glyphis sp. C collected in Western Australia have both a wider range in total vertebral count (i.e. 140-151 cf 147-148) and number of diplospondylous caudal centra (i.e. 64-70 cf 65-68) than that previously reported by Compagno \& Niem (1998). The extension in range of total vertebrae and diplospondylous caudal centra can most likely be attributed to the few specimens upon which previous counts were made. The length range of the animals captured, combined with maturity data suggest that they attain sexual maturity when $>1350 \mathrm{~mm}$ TL, at least, for females, and between 1191 and $1418 \mathrm{~mm}$ TL for males (Table 1). The original specimen collected in 2002 (994 mm TL), although shorter than the second largest male collected in June 2003, was found to be semi-mature. This maturity at a shorter length is likely to be attributed to its severe deformity, and the length may not be representative for an animal of similar age.

The occurrence of spinal deformations in three of the seven specimens collected from King Sound may also provide insight into the size of the Glyphis sp. C population in King Sound. Heupal et al. (1999) reports that spinal deformities in elasmobranchs are rare, with only a few cases of individuals of several species noted. The cause of the deformities is 
often unknown, but Heupal et al. (1999) attributes them to parasitic infection, arthritis,

injury, disease, tumours, malnutrition or genetic abnormality. Considering the high occur-

rence of this deformity, with almost half of those collected from King Sound possessing some degree of vertebral fusing, it is possible that the malformations are caused by a genetic abnormality, indicative of inbreeding within a small gene pool. Skeletal deformities as a result of inbreeding have been observed in hatchery reared fishes (Tave 1986), and other vertebrates, including humans (Jones 1996).

Glyphis sp. C possesses at least several morphological characters that may be reflective of this species persistence in the highly turbid macrotidal environment of King Sound, and indeed the rivers of the Northern Territory and Papua New Guinea. These include: a reduced eye (an average of $0.87 \%$ of the total length) which is approximately half the eye diameter of the bull shark Carcharhinus leucas (Carcharhinidae) (Taniuchi et al. 1991), a species known to enter freshwater rivers including the Fitzroy River (Thorburn et al. 2003); the occurrence of a large number of sensory ampullae covering the head (Fig. 4), which would compensate for any lack in visual capacity that this species may encounter while foraging in turbid waters; and the possession of large pectoral fins (and second dorsal fin) would assist in the motility and stability of this species in the shallow rapid flowing waters of King Sound (and rivers).

The feeder creeks of King Sound, and in particular those of the macrotidal Doctors Creek and Fitzroy River mouth, may be an important refuge for Glyphis sp. C. Furthermore, molecular data need to be collected in order to determine their population structure within King Sound, and the relationship of this population with those elsewhere in the Australian-New Guinean region.

\section{Acknowledgements}

These findings would not have been possible without the financial support of the Natural Heritage Trust and Murdoch University. Thanks to Dr Peter Last, Dr John Stevens, Andrew Rowland, Dr Howard Gill, Dr William White, Jim and Geraldine Kelly, Simon Visser, the Department of Fisheries Western Australia, the Kimberley Land Council (KLC), and the peoples of the west Kimberley who participated in the sampling and provided invaluable information on possible access sites and conditions.

\section{References}

Anon. (1993) Fitzroy Valley Irrigation, A Conceptual Study. For the Kimberley Resources Development Office. Prepared by ACIL Economics and Policy Pty Ltd, Kinhill Engineers Pty Ltd, Bryn Roberts and Associates and Water Authority of Western Australia.

Allen, G.R. (1975) A preliminary checklist of the freshwater fishes of the Prince Regent River Reserve north-west Kimberley, Western Australia. In: Miles, J.M. \& Burbidge, A.A. (Eds) A 
biological survey of the Prince Regent River Reserve North-west Kimberley, Western Australia in August, 1974. Wildlife Research Bulletin of Western Australia, 3, 1-116.

Allen, G.R. \& Leggett, R. (1990) A collection of freshwater fishes from the Kimberley region of Western Australia. Records of the Western Australian Museum, 14, 527-545.

Compagno, L.J.V. \& Niem, V.H. (1998) Order Carcharhinidae. In: Carpenter, K.E. \& Niem, V.H. (Ed) FAO Species Identification Guide for Fisheries Purposes. The Living Marine Resources of the Western Central Pacific. Volume 2. Cephalopods, Crustaceans, Holothurians and Sharks, FAO, Rome, 1312-1360.

Conrath, C.L. (2004) Reproductive Biology. In: Musick, J.A. \& Benfil, R. (Eds) Elasmobranch Fisheries Management Techniques, APEC Fisheries Working Group, 133-164.

Heupal, M.R., Simpfendorfer, C.A. \& Bennett, M.B. (1999) Skeletal deformities in elasmobranchs from Australian waters. Journal of Fish Biology, 54, 1111-1115.

Hutchins, J.B. (1977) The freshwater fish fauna of the Drysdale River National Park North Kimberley, Western Australia. In: Kabay, E.D. \& Burbidge, A.A. (Eds) A biological survey of the Drysdale River National Park North Kimberley, Western Australia in August, 1975. Wildlife Research Bulletin of Western Australia, 6, 1-133.

Hutchins, J.B. (1981) Freshwater fish fauna of the Mitchell Plateau Area, Kimberley, Western Australia. In: Biological Survey of Mitchell Plateau and Admiralty Gulf, Kimberley, Western Australia, Western Australian Museum Publication, Perth, pp 229-247.

Jones, S. (1996) In the Blood: God, Genes and Destiny, Flamingo, Hammersmith, London, 302 pp. Larson, H.K. (2000) Report to Parks Australia on Estuarine Fish Monitoring of Kakadu National Park, Northern Australia, Australia, Museum and Art Gallery of the Northern Territory, Darwin, 51 pp.

Last, P.R. \& Stevens, J.D. (1994) Sharks and Rays of Australia, CSIRO Division of Fisheries, CSIRO, Australia, $513 \mathrm{pp}$.

Morgan, D., Allen, M., Bedford, P. \& Horstman, M. (2002) Inland Fish Fauna of the Fitzroy River Western Australia (including the Bunuba, Gooniyandi, Ngarinyin, Nyikina and Walmajarri names). Unpublished Report to the Natural Heritage Trust, $56 \mathrm{pp}$.

Morgan, D., Allen, M.G., Bedford, P. \& Horstman, M. (2004) Fish fauna of the Fitzroy River in the Kimberley region of Western Australia - including the Bunuba, Gooniyandi, Ngarinyin, Nyikina and Walmajarri Aboriginal names. Records of the Western Australian Museum, 22, 147-161.

Pogonoski, J.J., \& Pollard, D.A. (2003) Northern river shark. In: Cavanagh, R.D., Kyne, P.M., Fowler, S.L., Musick, J.A. \& Bennett, M.B. (Eds) The Conservation Status of Australian Chondrichthyans: Report to the IUCN Shark Specialist Group Australia and Oceania Regional Red List Workshop, The University of Queensland, School of Biomedical Sciences, Brisbane, Australia, pp. 120-121.

Storey, A. (1998) Irrigated agriculture on the Fitzroy River: background and aims of the workshop. In: Storey, A. \& Beesley, L. (Eds) Limnology of the Fitzroy River, Western Australia: A Technical Workshop. Proceedings of a workshop held on the $18^{\text {th }}$ February 1998, at Edith Cowan University, Claremont Campus, Claremont, Western Australia, pp 1-2.

Taniuchi, T., Shimizu, M., Sano, M., Baba, O. \& Last, P.R. (1991) Description of freshwater elasmobranchs collected from three rivers in northern Australia. University Museum, University of Tokyo, Nature and Culture, 3, 11-26.

Tave, D. (1986) Genetics for Fish Hatchery Managers. AVI Publishing, Westport, Connecticut, 299 pp.

Thorburn, D.C., Peverell, S., Stevens, J.D., Last, P.R., \& Rowland, A.J. (2003) Status of Freshwater and Estuarine Elasmobranchs in Northern Australia. Unpublished Report to the Natural Heritage Trust, $79 \mathrm{pp}$. 